\title{
ЗАДЕРЖКА РОСТА ПРИ СИНДРОМЕ СИЛЬВЕРА-РАССЕЛА
}

Омарова М.M.

Магистрант 1 года, КМУ «ВЗОШ», ГКП на ПХВ «Городская поликлиника №4», Алматы, Казахстан

Введение. Синдром Сильвера - Рассела (ССР) является одним из синдромов, обусловленных хромосомными мутациями, для которого характерна задержка роста. При ССР чаще происходит мутации хромосом 7,11,15,17,18, которые и отвечают за рост человека [1]. Ребенок с ССР должен наблюдаться у узких специалистов, включая эндокринолога, гастроэнтеролога, ортопеда, невролога и психолога.

Ключевые слова: синдром Сильвера-Рассела (ССР), низкорослость, генетический анализ, гормон роста

Материалы и методы. Ребенок 3г 6 месяцев, рост при рождении 46 см. На момент осмотра рост ребенка $91 \mathrm{~cm}$, SDS роста-(-1,81), костный возраст соответствует на 2 года. Молекулярно-генетический анализ гена IGF от 23.11.2019г: определено нарушение метилирования Н19.Гипометилирование H19/IGF вследствие снижения экспрессии отцовской IGF2 и повышения экспрессии материнской Н19, что ведет к задержке роста. Заключение: клинический диагноз - ССР. Критерии Нетчинсона-Хирбисона: маленький рост для гестационного возраста, постнатальная задержка роста, выступающий лоб, низкий ИМТ. Дополнительный критерии: треугольное лицо, клинодактилия 5 пальца, микрогнатия, гипотрофия, задержка речи, гипогликемии (в анамнезе). Учитывая отставание в росте, подтверждённый ССР с декабря 2019 года ребенку назначена терапия гормоном роста. На фоне терапии за первые 10 месяцев прирост $+6,5$ см. Второй год терапии прирост $+5,5$ см, SDS роста $(-1,72)$, костный возраст на 4 года.

Результаты. На фоне терапии гормоном роста у ребенка прирост за 2 года +12 см, костный возраст соответствует 4 годам. Ребенок под контролем гормонального фона продолжает получать терапия гормоном роста.

Заключение. Таким образом, раннее обращение к детскому эндокринологу важно для детей ССР. Своевременная терапия низкорослости гормоном роста при ССР значительно улучшает показатели окончательного роста.

Список литературы:

1. Saal HM, Harbison MD, Netchine I. Silver-Russell Syndrome. 2002 Nov 2 [updated 2019 Oct 21]. In: Adam MP, Ardinger HH, Pagon RA, Wallace SE, Bean LJH, Mirzaa G, Amemiya A, editors. GeneReviews ${ }^{\circledR}$ [Internet]. Seattle (WA): University of Washington, Seattle; 1993-2021. PMID: 20301499.

Контактное лицо: Омарова Мадина Марипжановна, магистрант 1 года КМУ «ВЗОШ», врач эндокринолог, городская поликлиника №4, город Алматы, Казахстан

Телефон: +77782986824

E-mail: endo.dr@list.ru 